\title{
Drug utilization of antibiotics in post-operative cesarean section inpatients in tertiary care hospital: a prospective observational study
}

\author{
Srinivasa B., Basavaraj C. Kotinatot*
}

Department of Pharmacology, Belagavi Institute of Medical Science, Belagavi, Karnataka, India

\author{
Received: 04 March 2020 \\ Revised: 28 April 2020 \\ Accepted: 30 April 2020 \\ *Correspondence: \\ Dr. Basavaraj C. Kotinatot, \\ Email: drbckotinatot@gmail.com
}

Copyright: $@$ the author(s), publisher and licensee Medip Academy. This is an open-access article distributed under the terms of the Creative Commons Attribution Non-Commercial License, which permits unrestricted non-commercial use, distribution, and reproduction in any medium, provided the original work is properly cited.

\begin{abstract}
Background: The aim of this study is to evaluate the pattern and rational use of antibiotics in post-operative caesarean section (CS) inpatients in tertiary care teaching hospital, BIMS Belagavi.

Methods: This cross sectional prospective observational study was conducted from December 2019 to February 2020, prior permission from institutional ethics committee was taken. Detailed data of post-operative caesarean section (CS) inpatients including age, diagnosis, line of management, complications and any adverse effects if occurred during the study was collected and entered in a specially designed proforma and MS word excel and analyzed by descriptive statistics like percentage.

Results: Total 100 post-operative caesarean section inpatients were involved in the study. Most common indication for $\mathrm{C}$-section was cephalopelvic disproportion. Average no of antibiotics per prescription was 3.32. Most commonly prescribed antibiotic was cefotaxime $(27.71 \%)$ followed by gentamycin $(25.90 \%)$ and metronidazole $(24.59 \%)$. Majority $(90 \%)$ of patients who admitted for $\leq 3$ days $(66 \%)$ had received combination antibiotic i.e., cefotaxime, metronidazole and gentamycin. IV fluids (21.21\%) and analgesics (13.13\%) were most frequently prescribed concomitant drugs. Majority $(97.8 \%)$ of patients received parenteral preparation. 306 antibiotics $(92.17 \%)$ used were from national model list of essential medicines (NLEM) and 332 antibiotics (100\%). used were by generic name. Polypharmacy was 7.92 .

Conclusions: Cefotaxime was the most frequently prescribed antibiotic. Most of the antibiotics prescribed was rationally from NLEM and were by generic name.
\end{abstract}

Keywords: Drug utilization, Antibiotics, Cesarean section, Post-operative inpatients

\section{INTRODUCTION}

According to WHO and its extensive researches upto date like in world bank document, sepsis is the direct cause of $15 \%$ of the global maternal mortality, other studies also have estimated infections to be the cause of death especially in post-partum period in post-cesarean section patients which contributes to nearly $30 \%$ of the global maternal mortality cases. ${ }^{1,2}$
As per standard sources of information like national center for health statistics and the national hospital discharge survey, nearly more than $40 \%$ of surgical site infections (SSI) are preventable with appropriate use of prophylactic antibiotics. ${ }^{3}$

A complex balance between host defence mechanisms and bacterial virulence factors is responsible for development of clinical infection. Cesarean delivery alters this balance so as to predispose the patient to sepsis. Endometrium and peritoneal cavity invariably are 
contaminated during labor and abdominal delivery, with development of large numbers of highly pathogenic aerobic and anaerobic bacteria. ${ }^{4}$

Periodic evaluation of drug utilization patterns needs to be done to enable suitable modifications in the prescription of drugs to increase the therapeutic benefit and decrease the adverse effects.

Prescribing pattern studies are conducted to monitor, evaluate and if necessary, suggest modifications in the prescribing behaviour of medical practitioners to make medical care rational and cost effective. ${ }^{5}$

Hence forth, our study has been done to evaluate and analyze the prescribing pattern of antibiotics, and also to assess the rationality of the antibiotics use on maternal mortality in our institution.

\section{METHODS}

An observational and cross-sectional prospective study was conducted in OBG (obstetrics and gynaecology) post-operative wards, Belagavi institute of medical sciences; Belagavi for 3 months from December 2019 to February 2020.

A sample size of 100 patients fulfilling eligibility criteria was taken for the study. This is a convenient sample based on the number of caesarean section (CS) surgeries performed per week in our hospital.

Detailed data of post-operative caesarean section (CS) inpatients including age, diagnosis, line of management, complications and any adverse effects occurred during the study was collected and entered in a specially designed proforma. The prescribed drugs were assessed with respective national model list of essential medicines (NLEM), 2015 and the rationality of prescriptions was determined using the world health organization (WHO) indicators of drug use. ${ }^{6,7}$

\section{Inclusion criteria}

Post-operative caesarean section (CS) patients who received antibiotics till discharge in hospital during study period irrespective of age and diagnosis (either elective or emergency).

\section{Exclusion criteria}

Post-operative patients attending OBG OPD and discharged on the same day, patients admitted in other wards with other concomitant diseases, patients who were absconded or discharged against medical advice, patients who were already on antibiotic therapy for any infections, and patients whose data was insufficient and illegible.

Permission from institutional ethics committee (No. BIMS-IEC/66A/2019-2020) and HOD's of both obstetrics - gynaecology (OBG) and pharmacology department was taken.

Data entered in MS word excel was analyzed and interpretated using tables, graphs and descriptive statistics like percentage.

\section{RESULTS}

Total number of post-operative caesarean section in patients included in our study was 100. Majority of patients were of the age group between 18 to 40 years (98\%). Regarding the duration of stay of post-operative CS cases in hospital, 66 patients stayed for 1 to 3 days, 31 patients stayed for 4-6 days and 3 patients stayed for 7-8 days. All the patients were discharged in normal condition and none of patients in our study experienced any adverse events and untoward complications. Figure 1, represents 69 caesarean section cases were operated as elective surgery and 31 caesarean section cases were operated as emergency surgery.

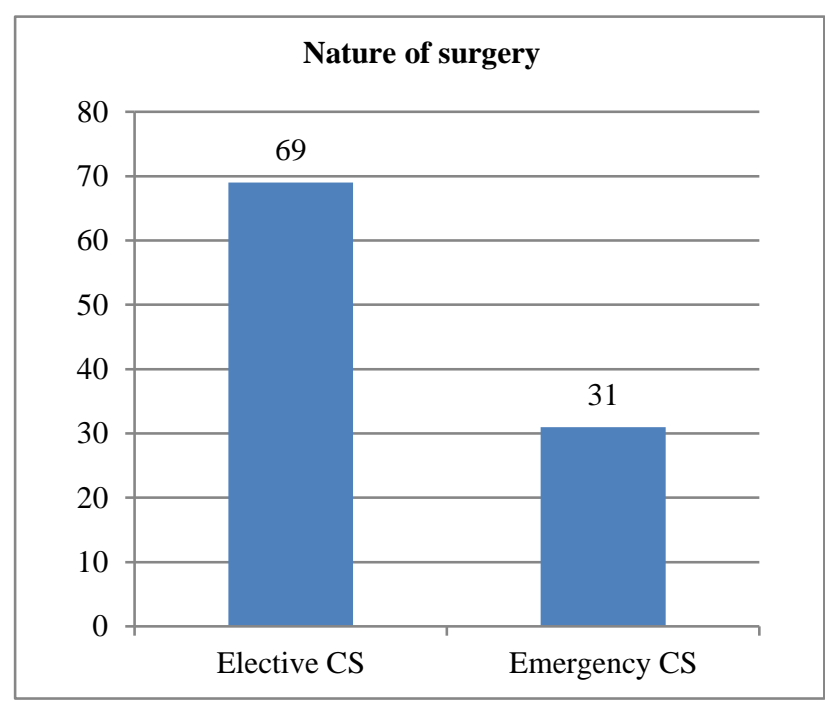

Figure 1: Categorization of patients based on nature of surgery.

Table 1 represents most common indication for caesarean section was cephalopelvic disproportion 36 (36\%) followed by foetal distress $20(20 \%)$, preterm labor $18(18 \%)$, post term labor 17 (17\%), IUGR 5 (5\%) and chronic health conditions 4 (4\%) (which included eclampsia, gestational diabetes mellitus and hypothyroidism).

Table 2 represents utilization patterns of different classes of antibiotics. Total number of antibiotics prescribed were 332. Among this cefotaxime $92(27.71 \%)$ was the most commonly prescribed antibiotic followed by gentamycin $86(25.90 \%)$ and metronidazole $78(23.49 \%)$. For the patients admitted for less than or equal to 3days duration, majority of cases $(90 \%)$ received combination of antibiotics that is cefotaxime, metronidazole and gentamycin. Piperacillin and tazobactam $26(7.83 \%)$ was 
used only in few cases where there were increased risk of sepsis and longer stay of patients. Excluding ciprofloxacin all the antibiotics were given through parenteral (IV) route. Ciprofloxacin (tab) was used orally only in 4 patients prophylactically who had regular history of UTI.

Table 1: Categorisation of different indications for caesarean section.

\begin{tabular}{|llll|}
\hline $\begin{array}{l}\text { S. } \\
\text { no. }\end{array}$ & $\begin{array}{l}\text { Indications for } \\
\text { caesarean section }\end{array}$ & $\begin{array}{l}\text { Total no. } \\
\text { of cases }\end{array}$ & $\begin{array}{l}\text { Percentage } \\
(\%)\end{array}$ \\
\hline $\mathbf{1}$ & $\begin{array}{l}\text { Cephalopelvic } \\
\text { disproportion }\end{array}$ & 36 & 36 \\
\hline $\mathbf{2}$ & Foetal distress & 20 & 20 \\
\hline $\mathbf{3}$ & Preterm labor & 18 & 18 \\
\hline $\mathbf{4}$ & Post term labor & 17 & 17 \\
\hline $\mathbf{5}$ & $\begin{array}{l}\text { IUGR (intra uterine } \\
\text { growth retardation) }\end{array}$ & 05 & 05 \\
\hline & $\begin{array}{l}\text { Chronic health } \\
\text { conditions } \\
\text { (eclampsia, } \\
\text { gestational diabetes } \\
\text { mellitus and } \\
\text { hypothyroidism) }\end{array}$ & 04 & 04 \\
\hline
\end{tabular}

Table 2: Prescribing pattern of different classes of antibiotics.

\begin{tabular}{|llll|}
\hline $\begin{array}{l}\text { S. } \\
\text { no. }\end{array}$ & Antibiotics & $\begin{array}{l}\text { Total no } \\
\text { of drugs }\end{array}$ & $\begin{array}{l}\text { Percentage } \\
(\%)\end{array}$ \\
\hline $\mathbf{1}$ & Cefotaxime & 92 & 27.71 \\
\hline $\mathbf{2}$ & Gentamycin & 86 & 25.90 \\
\hline $\mathbf{3}$ & Metronidazole & 78 & 23.49 \\
\hline $\mathbf{4}$ & Ceftriaxone & 46 & 13.85 \\
\hline $\mathbf{5}$ & $\begin{array}{l}\text { Piperacillin and } \\
\text { tazobactam }\end{array}$ & 26 & 7.83 \\
\hline $\mathbf{6}$ & Ciprofloxacin & 04 & 1.20 \\
\hline
\end{tabular}

Table 3: Prescribing pattern of different group of drugs in post-operative caesarean section inpatients.

\begin{tabular}{|llll|}
\hline $\begin{array}{l}\text { S. } \\
\text { no. }\end{array}$ & $\begin{array}{l}\text { Different group } \\
\text { of drugs }\end{array}$ & $\begin{array}{l}\text { No. of } \\
\text { drugs }\end{array}$ & $\begin{array}{l}\text { Percentage } \\
(\%)\end{array}$ \\
\hline $\mathbf{1}$ & Antibiotics & 332 & 41.92 \\
\hline $\mathbf{2}$ & Analgesics & 104 & 13.13 \\
\hline $\mathbf{2}$ & Gastro-protectives & 98 & 12.37 \\
\hline $\mathbf{3}$ & IV fluids & 168 & 21.21 \\
\hline $\mathbf{4}$ & Antifibrinolytics & 14 & 1.77 \\
\hline & $\begin{array}{l}\text { Miscellaneous } \\
\text { drugs (Iron } \\
\text { preparations, } \\
\text { oxytocin, } \\
\text { deriphylline, } \\
\text { insulin etc.) }\end{array}$ & 76 & 9.56 \\
\hline
\end{tabular}

Table 3 represents utilization pattern of different group of drugs (polypharmacy) in post op CS inpatients, among total 792 drugs used, antibiotics 332 (41.92\%) were most frequently prescribed followed by IV fluids 168 (21.21\%) and analgesics 104 (13.13\%). Least frequently used drugs were antifibrinolytics $14(1.77 \%)$ which included tranexamic acid. Miscellaneous drugs 76 (9.56\%) used were oxytocin, iron sucrose, calcium gluconate, magnesium sulphate, insulin, thyroxine, etophylline and theophylline (deriphylline) and potassium chloride.

Table 4 represents drugs use based on WHO indicator, polypharmacy with more than two drug use was $100 \%$ and most of the drugs were prescribed by generic name.

Table 4: WHO Indicators of drug use.

\begin{tabular}{|lll|}
\hline S. no. & Indicators assessed & Data value \\
\hline $\mathbf{1}$ & $\begin{array}{l}\text { Average number of drugs per } \\
\text { prescription }\end{array}$ & 7.92 \\
\hline $\mathbf{2}$ & $\begin{array}{l}\text { Average number of antibiotics } \\
\text { per prescription }\end{array}$ & 3.32 \\
\hline $\mathbf{3}$ & $\begin{array}{l}\text { Percentage of drugs prescribed } \\
\text { as per NLEM (\%) }\end{array}$ & 96.71 \\
\hline $\mathbf{4}$ & $\begin{array}{l}\text { Percentage of antibiotics } \\
\text { prescribed as per NLEM (\%) }\end{array}$ & 92.17 \\
\hline $\mathbf{5}$ & $\begin{array}{l}\text { Percentage of antibiotic drugs } \\
\text { prescribed by generic name (\%) }\end{array}$ & 100 \\
\hline $\mathbf{6}$ & $\begin{array}{l}\text { Percentage of drugs prescribed } \\
\text { in hospital pharmacy (\%) }\end{array}$ & 92.93 \\
\hline $\mathbf{7}$ & $\begin{array}{l}\text { Percentage of drugs prescribed } \\
\text { outside hospital pharmacy (\%) }\end{array}$ & 7.07 \\
\hline $\mathbf{8}$ & $\begin{array}{l}\text { Most common route of drug } \\
\text { administration of all drugs- } \\
\text { parenteral (\%) }\end{array}$ \\
\hline
\end{tabular}

\section{DISCUSSION}

Women undergoing caesarean section have a five to 20fold greater chance of getting an infection compared to women who give birth vaginally, and the routine use of antibiotics at cesarean section reduces the risk of infection. ${ }^{8}$ In cesarean section, post-operative infections are likely to be caused by Staphylococcus epidermidis, Staphylococcus aureus, group B Streptococci or Enterococcus. The result from the study, showing that $100 \%$ of the women undergoing caesarean section were prescribed antibiotics are therefore not surprising and in line with WHO recommendation. According to WHO, cephalosporins are the first line antibiotics prescribed in CS patients post-operatively. ${ }^{9,10}$

The present study showed majority of CS patients were of the age group between 18-40 years and are in comparison with several similar studies. ${ }^{11,12}$ In our study most commonly prescribed antibiotic was cefotaxime and is in accordance with WHO and similar study done by Shamna et al whereas in study done by Sharma et al, fluoroquinolones are preferred followed by $3^{\text {rd }}$ generation cephalosporins..$^{10-12}$ In our study average no of antibiotics prescribed per patient was 3.32 and more over 
majority of CS patients $(66 \%)$ were prescribed antibiotics only for less than or equal to 3 days unlike in study done by Sharma et al, there was over use of antibiotics for long periods (10 days). ${ }^{12}$

In our study switch over of parenteral antibiotic to oral tablets was on and around day 4 in majority of cases $(66 \%)$. In our study most of the drugs and antibiotics prescribed were from NLEM $(96.71 \%, 92.17 \%)$ and by generic name $(98.3 \%, 100 \%)$ respectively. Majority of the drugs prescribed were from our hospital pharmacy $(92.93 \%)$ thereby patients were not given financial burden and instead were given cost effective treatment.

None of the patients experienced any of the adverse events and untoward complications. Majority of women and their babies were healthy and in normal condition during discharge. Hence forth maternal mortality was almost nill.

The only limitation findings in our study were average number of drugs per prescription (polypharmacy) was 7.92 , mild over use of piperacillin-tazobactam $(7.83 \%)$ in high risk patients and insufficient data on socio-economic status of CS patients.

\section{CONCLUSION}

Our study suggests antibiotics were used judiciously in short course, minimal side effects and in cost effective manner. $3^{\text {rd }}$ generation cephalosporins (cefotaxime) were the most frequently prescribed antibiotics. Prescriptions of antibiotics were from essential drug list and were of generic drugs. Antibiotics prescribed in combination i.e. cefotaxime, metronidazole and gentamycin was effective in patients admitted for $\leq 3$ days and were discharged earlier. Polypharmacy $(7.92 \%)$ was significantly high. Study highlights the need to minimize the average number of drugs per prescription. Regular educational interventions needed to improve prescribing practices of doctors at different levels may further promote rational prescribing.

\section{ACKNOWLEDGEMENTS}

We thank our director, medical superintendent, HOD of pharmacology and OBG department for permitting us to collect data. We also acknowledge the scholars whose articles are cited and included in our article as references.

Funding: No funding sources Conflict of interest: None declared

Ethical approval: The study was approved by the Institutional Ethics Committee

\section{REFERENCES}

1. Starrs A. The safe motherhood action agenda: priorities for the next decade. New York: Safe motherhood interagency group, Family Care International; 1998:37.

2. Li XF, Fortney JA, Kotelchuck M, Glover LH. The postpartum period: the keytomaternalmortality. Int $\mathrm{J}$ Gynecol Obstet. 1996;54:1-10.

3. Dipiro JT. Pharmacotherapy - a path physiologic approach. 5th ed; 1999: 2111-2120.

4. Thigpen BD, Hood WA, Chauhan S, Bufkin L, Bofill J, Magann E, et al. Timing of prophylactic antibiotic administration in the uninfected laboring gravida: a randomized clinical trial. Am J Obstet Gynecol. 2005;192(6):1864-8.

5. Shankar PR, Pai R, Dubey AK, Upadhyay DK. Prescribing patterns in the orthopaedics outpatient department in a teaching hospital in Pokhara, Western Nepal. Kathmandu Univ Med J (KUMJ). 2007;5:16-21.

6. National List of Essential Medicines (NLEM) India; 2015:117.

7. How to Investigate Drug Use in Health Facilities: Selected Drug Use Indicators - EDM Research Series No. 007; 1993.

8. Smaill FM, Gyte GM. Antibiotic prophylaxis versus no prophylaxis for preventing infection after cesarean section. Cochrane Database Syst Rev. 2010;20:CD007482.

9. Katzung BG, Masters SB, Trevo AJ. Basic and clinical Pharmacology. 12th edition. New Delhi: Tata McGrew Hill Education Private Limited. 2012;2012:910-1.

10. Schalkwyk J, Eyk N. Society of Obstetricians and Gynaecologists of Canada Infectious Diseases Committee. Antibiotic prophylaxis in obstetric procedures. J Obstet Gynaecol Can. 2010;32:878-92.

11. Shamna MS, Kalaichelvan VK, Marickar FYM, Manavalan R, Kannan K, Deepu S. A Study on Pattern of Using Prophylactic Antibiotics in Caesarean Section. IOSR J Pharm. 2015;5(1):12-18.

12. Sharma M, Sanneving L, Mahadik K, Santacatterina M, Dhaneria S, Lundborg CS, et al. Antibiotic prescribing in women during and after delivery in a non-teaching, tertiary care hospital in Ujjain, India: a prospective cross-sectional study. J Pharm Policy Pract. 2013;6:9.

Cite this article as: Srinivasa B, Kotinatot BC. Drug utilization of antibiotics in post-operative caesarean section inpatients in tertiary care hospital: a prospective observational study. Int J Basic Clin Pharmacol 2020;9:859-62. 